\title{
Effect of subacute intoxication with nitrite on AMP-deaminase activity in skeletal muscles of common carp (Cyprinus carpio)
}

\author{
Sedigheh Saberifar ${ }^{1}$, Ali Shahriari ${ }^{1, *}\left(\mathbb{D}\right.$, Rahim Peyghan $^{2}$ \\ ${ }^{1}$ Shahid Chamran University of Ahvaz, Faculty of Veterinary Medicine, Department of Basic Sciences, Ahvaz, Iran \\ ${ }^{2}$ Shahid Chamran University of Ahvaz, Faculty of Veterinary Medicine, Department of Clinical Sciences, Ahvaz, Iran
}

\section{Article History}

Received 14 January 2020

Accepted 28 April 2020

First Online 04 May 2020

\section{Corresponding Author}

Tel.: +0098-6133330073

E-mail: a.shahriari@scu.ac.ir

\section{Keywords}

AMP-deaminase

Common carp

Kinetics

Hypoxia

$\mathrm{NO}_{2}$

\begin{abstract}
This study was aimed to evaluate the effects of intoxication of common carp with nitrite on some properties of Adenosine $5^{\prime}$-monophosphate (AMP) deaminase in the skeletal muscle. $\mathrm{LC}_{50}$ value was determined to be $512 \mathrm{mg} / \mathrm{L}$. After estimating the $\mathrm{LC}_{50}$, fish were exposed to $153 \mathrm{mg} / \mathrm{L}\left(30 \% \mathrm{LC} \mathrm{C}_{50}\right)$ and sampling was done at $0,24,48,72$, and $96 \mathrm{~h}$ after exposure. Cytosolic AMP deaminase was purified from the skeletal muscle of the control and experimental groups. AMP-deaminase showed Hill kinetics with an $S_{0.5}$ value for AMP of $2.52 \pm 0.031$ and $1.45 \pm 0.07 \mathrm{mM}$, a Hill coefficient $\left(\mathrm{n}_{H}\right)$ of $1.35 \pm 0.051$ and $1.79 \pm 0.60$, and a maximal velocity $\left(\mathrm{V}_{\max }\right)$ of $133.39 \pm 28$ and $98.9 \pm 38$ $\mathrm{IU} / \mathrm{mg}$ protein for the control and experimental groups, respectively after $96 \mathrm{~h}$. The optimum $\mathrm{pH}$ was reduced during nitrite intoxication. The maximal activation of the enzyme was at 45 으. Also, activation energy declined in the experimental groups. Fenton reaction showed that the enzyme was tolerant to free radicals.

According to the results, AMP deaminase activity in the common carp's muscles increased following nitrite intoxication. Also, acidic condition increased AMP deaminase activity that could be an adaptive response to hypoxic condition caused by nitrite intoxication.
\end{abstract}

\section{Introduction}

Nitrite is one of the most common pollutants in water systems, which accumulates by bacterial nitrification of ammonia or by denitrification of nitrate (Martinez \& Souza, 2002). Nitrite concentrations are increasing in freshwater ecosystems as a consequence of several anthropogenic sources, such as effluents from industries producing metals, dyes, and celluloids; urban sewage effluents; and aquaculture (Jensen, 2003; Camargo \& Alonso, 2006; Zhang et al., 2019). In some eutrophic shallow lakes, an increased concentration of nitrite is usually observed during the degradation of cyanobacterial blooms (Qin et al., 2007; Zhang et al., 2019). Nitrite as an intermediate which produced during oxidation of ammonium to nitrate causes methemoglobinemia and hypoxia (Russo, 1985; Lewis \& Morris, 1986; Eddy \& Williams, 1987; Martinez \& Souza, 2002; Jensen, 2003; Kroupova et al., 2006; Kroupova et al., 2016; Zhang et al., 2019).

Anoxia tolerance is strengthened by welldeveloped mechanisms of anoxia-induced metabolic rate depression, high levels of carbohydrate reserves in all tissues, and a novel capacity to avoid acidosis and end product accumulation by processing lactate to form ethanol and $\mathrm{CO}_{2}$ excreted by the gills (Hochachka \& Somero, 1984; Hermes-Lima \& Zenteno, 2002; Lushchak, V.I., Lushchak, L.P., Mota, \& Hermes-Lima, 2001; Bickler \& Buck, 2007; Vornanen, M., Stecyk, J.A.W., \& Nilsson, G.E., 2009; Fago \& Jensen, 2015 ; 
Fagernes et al., 2017; Gattus et al., 2018)

The first step to compensate for the energy loss in hypoxia is to consume high-energy compounds, such as ATP and phosphocreatine, which can be stored in a limited amount (Hochachka \& Somero, 1984; Wang, Y., 2011). Another limitation in providing energy is metabolic acidosis, likely to be caused by the decrease in the $\mathrm{pH}$ of the muscle when lactate is produced during glycogen utilization. Thus, during intense exercise, the deamination of AMP to $\mathrm{NH}_{3}$ happens via AMP deaminase, adenylate kinase reaction is activated, and the adenylate energy charge is increased (Lushchak, Smirnova, \& Storey, 1998; Mandic, M., \& Regan, M.D., 2018; Omlin, T., \& Weber, J.M., 2010); as a result, the energy charge of the cell is maintained at an acceptable level. AMP deaminase is one of the purine nucleotide cycle enzymes and the key enzyme in preserving the viability of the cell under stressful conditions. Thus, the behavior of AMP deaminase is very important in hypoxic and anoxic conditions which are caused by several factors, including nitrite intoxication. Moreover, this enzyme could contribute to the adaptation of fish to nitrite-induced anoxic conditions.

Cyprinidae family is one of the most diverse bony fish families reared across the world. Common carp (Cyprinus carpio) is one of the most resistant species to environmental stresses, especially hypoxia (Svobodova et al., 2005; Lushchak et al., 2005, Bickler \& Buck, 2007; Lardon et al., 2013; Moyson, S., 2015; Gattuso, 2018) In recent years, more attention has been paid to the harmful effects of nitrite on fish. Increased nitrite concentrations in water are also one of the most frequent problems encountered in both aquariums and fish farms (Voslarova, Pistekova, Svobodova, \& Bedanova, 2008; Kroupova et al., 2010).

In the study of Woo \& Chiu (1996) metabolic and osmoregulatory responses of the Sea Bass Lates calcarifer to nitrite exposure reviewed. It is postulated that this event probably represents an adaptive strategy employed by the sea bass to counteract nitrite toxicity. Kaminsky \& Kosenko (2010) had studied AMP deaminase and adenosine deaminase activities in liver and brain regions in acute ammonia intoxication and subacute toxic hepatitis. They concluded, those are upregulated under pathological conditions, probably in order to overcome compensatory synthesis of adenylates, to ensure prompt adenylate pool depletion and reduce the adenylate energy charge in liver and selected brain regions.

AMP deaminase has been identified in muscle of several fish species. Nitrite is a natural component of the nitrogen cycle in ecosystems, and its presence in the environment is a potential problem due to its welldocumented toxicity (Kroupova, H., Machova, J., \& Svobodova, Z., 2005). Our aim was to describe the effects of intoxication of common carp with nitrite on AMP deaminase activity due to its key role in providing energy in these conditions for adaptation.

\section{Materials and Methods}

\section{Fish Maintenance}

Sample common carp (C. carpio L.), with a mean weight of $67.3 \pm 14.7 \mathrm{gr}$, were obtained from commercial farms. For two weeks prior to the experimentation, the fish were kept for adaptation to the experimental condition. Water chemical factors were as follows: Temperature, $26-28{ }^{\circ} \mathrm{C}$; Ammonia, $0.01 \mathrm{ppm}$; nitrite, $0.02 \mathrm{ppm}$; nitrate, $5 \mathrm{ppm}$; chloride, $0.5 \mathrm{ppm}$; total hardness, $180 \mathrm{ppm}$; $\mathrm{pH}$, 8-8.4; total salinity, $1.2 \mathrm{ppt}$; and $\mathrm{O}_{2}, 8 \mathrm{ppm}$. The fish were fed twice daily with commercial concentrate food ( $2 \%$ of body weight). During this period, $20 \%$ of the volume of water was replaced every 48h. All procedures were done as approved by ethics committee of Shahid Chamran University of Ahvaz.

\section{LC 50 Calculation}

Two hundred and ten Common carp were prepared from commercial provider and divided randomly in tanks $(n=10)$ The fish were exposed to different concentrations of nitrite, including 0,450,500, 530, 550, 560, and $600 \mathrm{mg} / \mathrm{L}$. Each treatment was done in triplicate. Then, the percentage of mortalities was recorded in the $96 \mathrm{~h}$ group. $\mathrm{LC}_{50}$ in $96 \mathrm{~h}$ was estimated using Probit software. $\mathrm{LC}_{50}$ value was calculated to be $512 \mathrm{mg} / \mathrm{L}$.

\section{Experimental Design}

For sub-lethal concentration, we used $30 \%$ of the concentration of the estimated LC50 $(153 \mathrm{mg} / \mathrm{L}$ which was used as Sodium nitrite: $230 \mathrm{mg} / \mathrm{L}$ ). Ninety healthy fish were divided 6 tanks ( $n=15)$. Fish divided to nitrite exposed and control group, each in triplicate. Sampling was done at 0 (control group), 24, 48, 72, and $96 \mathrm{~h}$ after exposure to nitrite. At each sampling time 3 fish was captured from each group. For this, fish were anesthetized with 2-phenoxyethanol, then fish were killed by trans-spinal dissection, and the muscles ( $\sim \mathrm{g}$ ) of the fish was taken from the dorsal region. All procedures were done as approved by ethic committee of the Shahid Chamran University of Ahvaz.

\section{AMP-deaminase Purification}

White skeletal muscles were washed in normal saline and homogenized in homogenate buffer containing $80 \mathrm{mM} \mathrm{KCl}, 2 \mathrm{mM}$ EDTA, $54 \mathrm{mM} \mathrm{KH}_{2} \mathrm{PO}_{4}, 35$ $\mathrm{mM} \mathrm{K}_{2} \mathrm{HPO}_{4}$, and $\mathrm{pH} 6.5$ with a few crystals of PMSF (Sigma Aldrich Chemical Co. USA.) to inhibit protease. The homogenate was centrifuged at $12,000 \mathrm{~g}$ for $10 \mathrm{~min}$ (Eppendorf, Germany), and the supernatant as a crude extract was removed. Enzyme purification was performed according to affinity chromatography with some modifications in the Smiley method (1967). Phosphocellulose (Sigma Aldrich Chemical Co. USA.), as 
a resin, was kept $24 \mathrm{~h}$ at $4^{\circ} \mathrm{C}$ for equilibration; then, it was added to the supernatant and the suspension was stirred for $2 \mathrm{~h}$ on ice. This made the enzyme to attach to phosphocellulose. Again, the slurry was centrifuged at $12,000 \mathrm{~g}$ for $10 \mathrm{~min}$ and the supernatant was discarded. To delete the remained proteins, the pellet was washed with homogenate buffer. Finally, the slurry was poured into a column and washed with a progressive concentration of $\mathrm{KCl}$ (Sigma Aldrich Chemical Co. USA.) $(0.4,1,1.5,2 \mathrm{M}, \mathrm{pH} 7)$, which facilitated the binding between the enzyme and AMP. Finally, AMP deaminase was purified with $0.4 \mathrm{M} \mathrm{KCl}$.

\section{SDS-polyacrylamide Gel Electrophoresis}

SDS-polyacrylamide gel electrophoresis was performed according to the method suggested by Laemmli (1970). Thus, $10 \%$ separating and $5 \%$ acrylamide (Cinnagen, Iran) stacking gels were used and they were stained with Coomassie Brilliant Blue R-250 (Merck, Germany).

\section{Enzyme Assays}

AMPD activity was measured using a Microplate spectrophotometer (Power Wave Xs2, Biotek) at $285 \mathrm{~nm}$ for 5 minutes. The difference in the molar absorption of AMP and IMP at $285 \mathrm{~nm}$ is 300 (Smiley, Berry, \& Suelter, 1967). The reaction volume of $200 \mu$ contained $50 \mathrm{mM}$ imidazole- $\mathrm{HCl}$ (Merck, Germany) (pH 7), 2 mM AMP (Sigma Aldrich Chemical Co. USA), and $100 \mathrm{mM} \mathrm{KCl}$. Also, the protein concentration was measured by the Bradford method with Coomassie brilliant blue G-250 (Merck, Germany) and Bovine serum albumin (Merck, Germany) as a standard (Bradford, 1976).

To determine the relationships between the effects of $\mathrm{pH}$ and the AMP deaminase activity, a wide range of $\mathrm{pH}$ (4 to 9), which contained $25 \mathrm{mM}$ imidazole$\mathrm{HCl}$ and Tris- $\mathrm{HCl}$ Buffer (Cinnagen, Iran) with $\mathrm{pH}=7$, were used. To evaluate the effects of temperature on AMP deaminase activity, the enzyme activity was assayed at $4,10,15,20,37,45$ oC in an assay buffer.

\section{Fenton Reaction}

A Fenton system was designed for evaluating the effects of reactive oxygen species on enzyme tolerance. The volume reaction contained assay buffer, $100 \mu \mathrm{M}$ $\mathrm{H}_{2} \mathrm{O}_{2}$ and $5 \mu \mathrm{M} \mathrm{FeSO}$ prepared at a potassium buffer with $\mathrm{pH}=7$ (Lushchak, Husak, \& Storey, 2008).

\section{Kinetic Measurement}

The activity of AMPD of white skeletal muscle of common carp was evaluated daily to determine the halflife of the enzyme. The half-life of the enzyme was defined as the day that the enzyme activity was reduced to half ( $50 \%$ enzyme activity). Kinetic studies $\left(K_{m}, V_{\max }\right)$ were done at various concentrations of the substrate $(0$, $0.5,1,1.5,2,2.5,3,4$, and $5 \mathrm{mM}$ ) and in an assay buffer using a nonlinear regression kinetic software.

\section{Statistical Analysis}

The normality of the data was examined using the Kolmogorov-Smirnov test. Data analysis was performed using one-way ANOVA to determine the significant difference between the treatments at $P \leq 0.05$. If a significant difference was found, Tukey's multi-domain test post-test was used to compare the results. The statistical analysis of the data was done using SPSS 20 (SPSS for Windows, version 20).

\section{Results}

\section{LC50}

According to the mortality recorded following $96 \mathrm{~h}$ exposure to different levels of sodium nitrite (Figure 1). Mortality and behavioral changes were observed during 96 h. Finally, LC50-96 h of nitrite was estimated at 512 $\mathrm{mg} / \mathrm{L}$. by Probit. The maximum acceptable concentration (MAC) of nitrite was determined 51/24 $\mathrm{mg} / \mathrm{L}$.

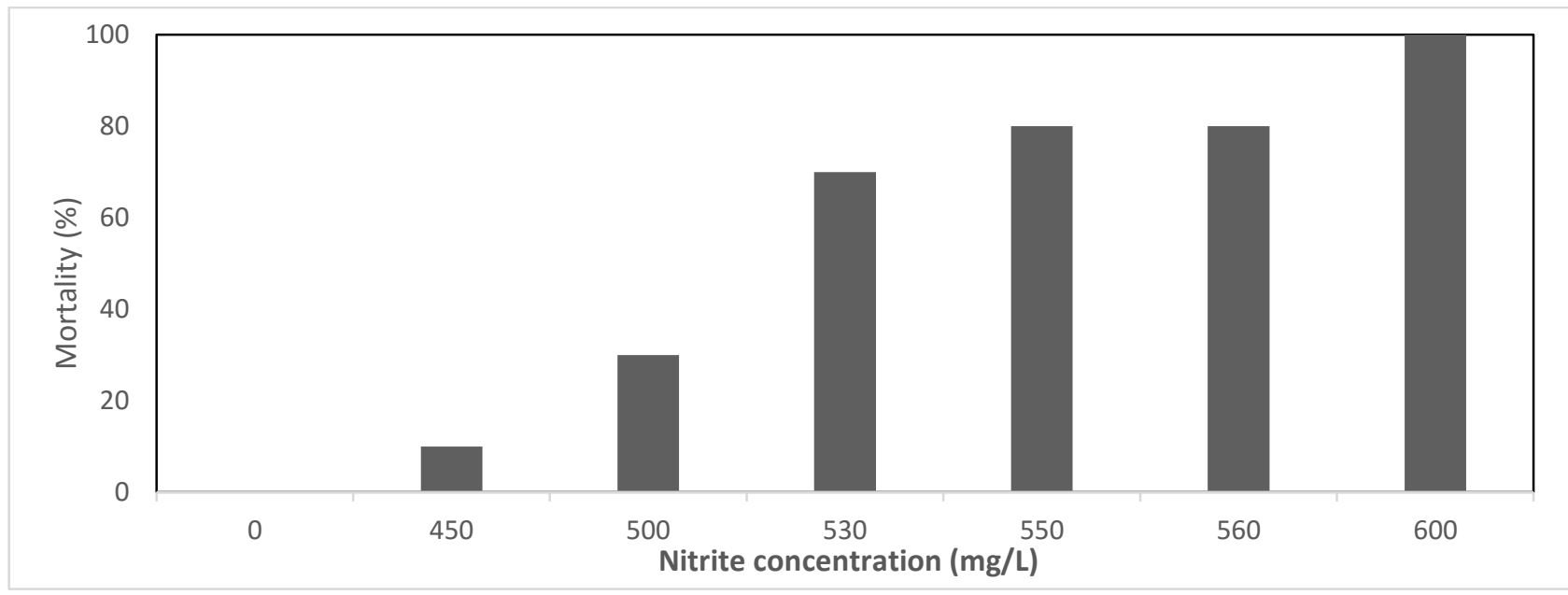

Figure 1. Mortality rate of Common carp exposed to different nitrite concentrations after $96 \mathrm{~h}$ 


\section{Purification and Molecular Mass Evaluation}

The SDS-PAGE showed that the enzyme was electrophoretically homogenous, with single band and molecular mass of AMPD was estimated to be $55 \mathrm{kDa}$ (Figure 2). The specific activity of the purified enzyme was $1200-1300 \mathrm{U} / \mathrm{mg}$ protein.

\section{Kinetics}

Table 1 shows the kinetic properties of AMPdeaminase $\left(\mathrm{K}_{\mathrm{m}}, \mathrm{V}_{\max }\right.$, and $\left.\mathrm{n}_{\mathrm{H}}\right)$. The data indicated that hypoxia due to intoxication with nitrite modified all kinetic parameters. The substrate affinity data showed a Hill plot $(P<0.05)$, and showed cooperative binding of $A M P$, that increased in treatment groups.

In experimental groups, the enzyme affinity for the substrate and $V_{\max }$ reduced in comparison to those of the control group $(P<0.05)$. For example, in treatment 96 $h$, $S_{0.5}$ and $V_{\max }$ increased by 1.7 - and 1.3-fold, respectively. A higher $S_{0.5}$ means that less of the substrate is required to reach half of $V_{\max }$. With increasing nitrite intoxication, $\mathrm{S}_{0.5}$ levels decreased in the treatment groups.

\section{pH-dependency}

Figure 3 illustrates the effects of $\mathrm{pH} 4$ to 9 on the activity of AMP-deaminase. The highest enzyme activity $(\mathrm{P}<0.05)$ in the control group was at $\mathrm{pH} 7$, but the optimum $\mathrm{pH}(\mathrm{pH} 6.5)$ was observed in the experimental groups that were exposed to nitrite and hypoxia. Also,
$30 \%$ and $50 \%$ reduction in the activity of AMP deaminase was recorded at $\mathrm{pH} 6$ and 7, respectively. Experimental groups showed a similar pattern, with the optimum $\mathrm{pH}$ felled from 7 to 6.5. Optimum $\mathrm{pH}$ in experimental groups was slightly more acidic. The effect of intoxication in causing a acidic shift in $\mathrm{pH}$ optimum is observed. On both sides of the optimum $\mathrm{pH}$, the enzyme activity decreased with a steep slope.

\section{Oxidative Stress}

One of the most important sources of reactive oxygen species (ROS) in biological systems is the Fenton reaction. The time needed to complete a Fenton reaction will depend on the many variables, most notably catalyst dose and wastewater strength. For typical reaction times are 30 - 60 minutes. For more complex or more concentrated wastes, the reaction may take several hours (Zhang, 2005). When the Fenton is completed, the activity of the enzyme is compared. The enzyme activity was evaluated in $10,20,30,40,50$, and $60 \mathrm{~min}$ after the start of the reaction. The effects of any part of the reaction $\left(\mathrm{Fe}^{2+}, \mathrm{H}_{2} \mathrm{O}_{2}\right)$, separately or in combination with other parts, were calculated. $\mathrm{FeSO}_{4}$ did not affect AMPD activity in the control group. In this, the $\mathrm{Fe}^{2+}$ or $\mathrm{Fe}^{3+}$ whitout $\mathrm{H}_{2} \mathrm{O}_{2}$ didn't produce $\mathrm{ROS}$ and AMPD activity remained constant, while the AMPD activity in the control group reached half-maximal activity after 50 min by using $\mathrm{H}_{2} \mathrm{O}_{2}$ in the reaction. Inactivation of AMPD had a slowly decreasing. The combination of $\mathrm{FeSO}_{4}$ and $\mathrm{H}_{2} \mathrm{O}_{2}$ reduced sharply the

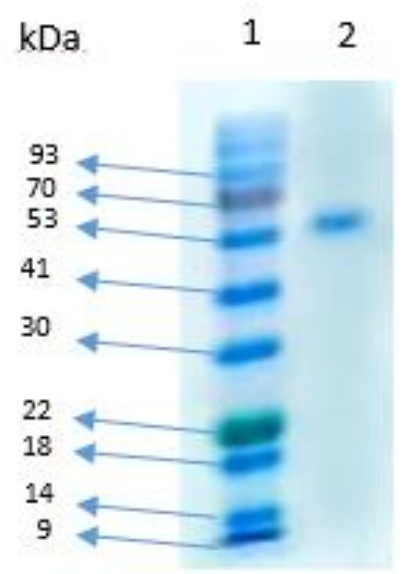

Figure 2. Determination of the molecular weight of AMPD (treatment 96h) by SDS-PAGE. Lane 2 shows the position of AMP deaminase and lane 1 shows the standard proteins.

Table 1. The Kinetic properties of AMP-deaminase from white skeletal muscle of Common carp in control group and comparison with treatment groups. Data are expressed as means \pm S.D., Significantly different $(P<0.05), n=3$. The star indicates a significant difference in compare to the control group

\begin{tabular}{lccc}
\hline & $\mathrm{V}_{\max }$ & $\mathrm{S}_{0.5}(\mathrm{mM})$ & $\mathrm{n}_{\mathrm{H}}(\mathrm{I})$ U./mg protein) \\
\hline Control & $13.39 \pm 0.28$ & $2.52 \pm 0.03$ & $1.35 \pm 0.05$ \\
$24 \mathrm{~h}$ & $11.80 \pm 1.28^{*}$ & $2.19 \pm 0.09^{*}$ & $1.67 \pm 0.08^{*}$ \\
$48 \mathrm{~h}$ & $8.21 \pm 0.43^{*}$ & $1.82 \pm 0.10^{*}$ & $1.94 \pm 0.06^{*}$ \\
$72 \mathrm{~h}$ & $7.87 \pm 0.19^{*}$ & $1.75 \pm 0.16^{*}$ & $1.59 \pm 0.60^{*}$ \\
$96 \mathrm{~h}$ & $9.89 \pm 0.38^{*}$ & $1.45 \pm 0.07^{*}$ & $1.79 \pm 0.60^{*}$ \\
\hline
\end{tabular}


enzyme activity by $50 \%$ in the control group after 20 min. Similar results were recorded in the $96 \mathrm{~h}$ group (Figure 4).

\section{Half-life}

To obtain enzyme stability at $4 \stackrel{\circ}{ } \mathrm{C}$, the enzyme activity was measured in an assay buffer daily. Intoxication with nitrite decreased the enzyme activity and stability over time in the treatment groups. The halflife $\left(t_{1 / 2}\right)$ of an enzyme is the time it takes for the activity to reduce to a half of the original activity (Chaplin, $M$, 2004). The half-life for the control and experimental groups was 7.5 and 6 days, respectively (Figure 5).

\section{Urea Inhibition}

Half-maximal inhibition ( $I_{50}$ value) in the control group was $0.07 \mathrm{mM}$, while it increased to $0.15 \mathrm{mM}$ in the treatment $96 \mathrm{~h}$ group $(P<0.0001$, Figure 6). According to the enzyme activity in experimental group, the slope decreased more slowly than in the control group, meaning that higher concentrations of urea than control were required to reduce the enzyme activity by $50 \%$.

\section{Temperature and Activation Energy}

The influences of temperature on AMPD activity is shown in Figure 7. The maximal activity was seen at $45^{\circ} \mathrm{C}$. For high temperatures $\left(37^{\circ} \mathrm{C}\right)$, the activation energy for the control group was $18.84 \pm 1.40 \mathrm{kcal} / \mathrm{mol}$ while it was $9.685 \pm 0.67 \mathrm{kcal} / \mathrm{mol}$ for the $96 \mathrm{~h}$ group (Figure 7). The activation energy for temperatures below $370 \mathrm{C}$ for control and nitrite exposed groups were $21.74 \pm 0.54$ and $11.36 \pm 0.89 \mathrm{kcal} / \mathrm{mol}$, respectively.

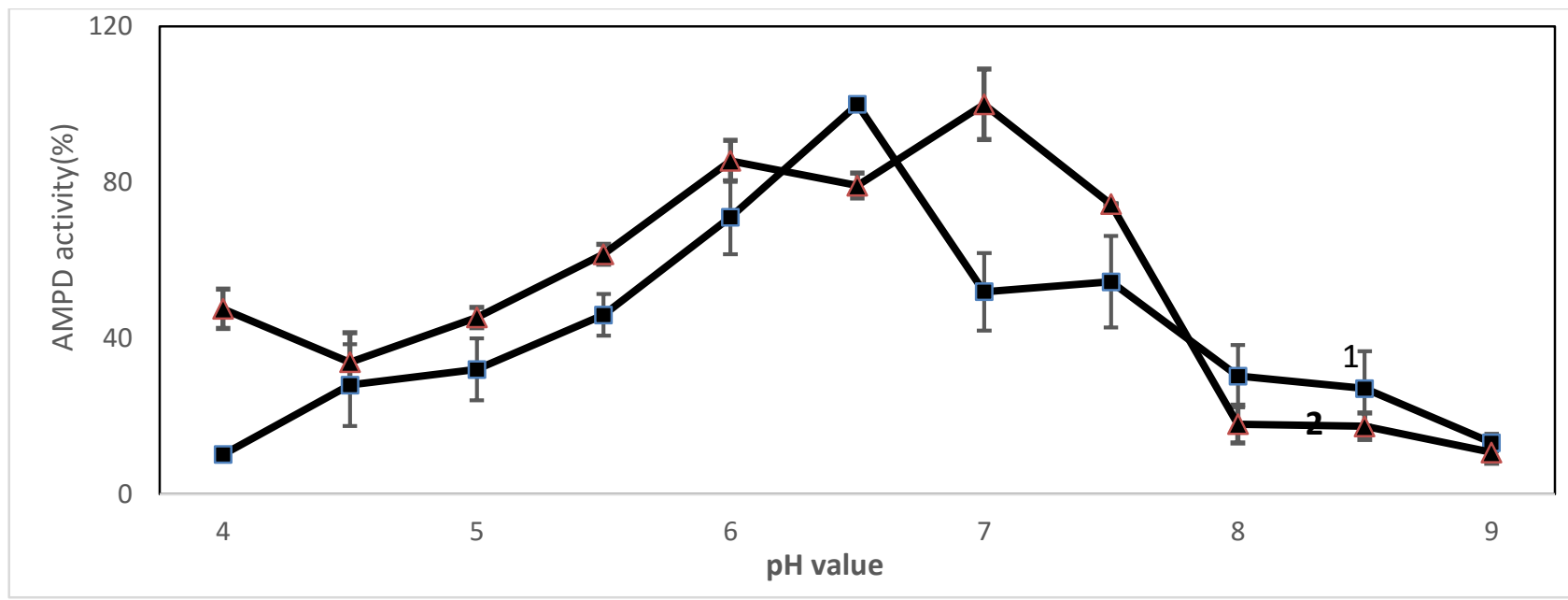

Figure 3. The effects of $\mathrm{pH}$ on the AMPD activity in muscles of Common carp in the control (1) and the experimental groups (2). Assay conditions: pH 7.0, $25 \mathrm{mM}$ imidazole- $\mathrm{HCl}$ buffer, $25 \mathrm{mM}$ Tris- $\mathrm{HCl}$ Buffer, adenosine monophosphate $2 \mathrm{mM}, \mathrm{KCl} 150 \mathrm{mM}, 25 \circ \mathrm{C}, \mathrm{P}<0.05$ and $n=3$.

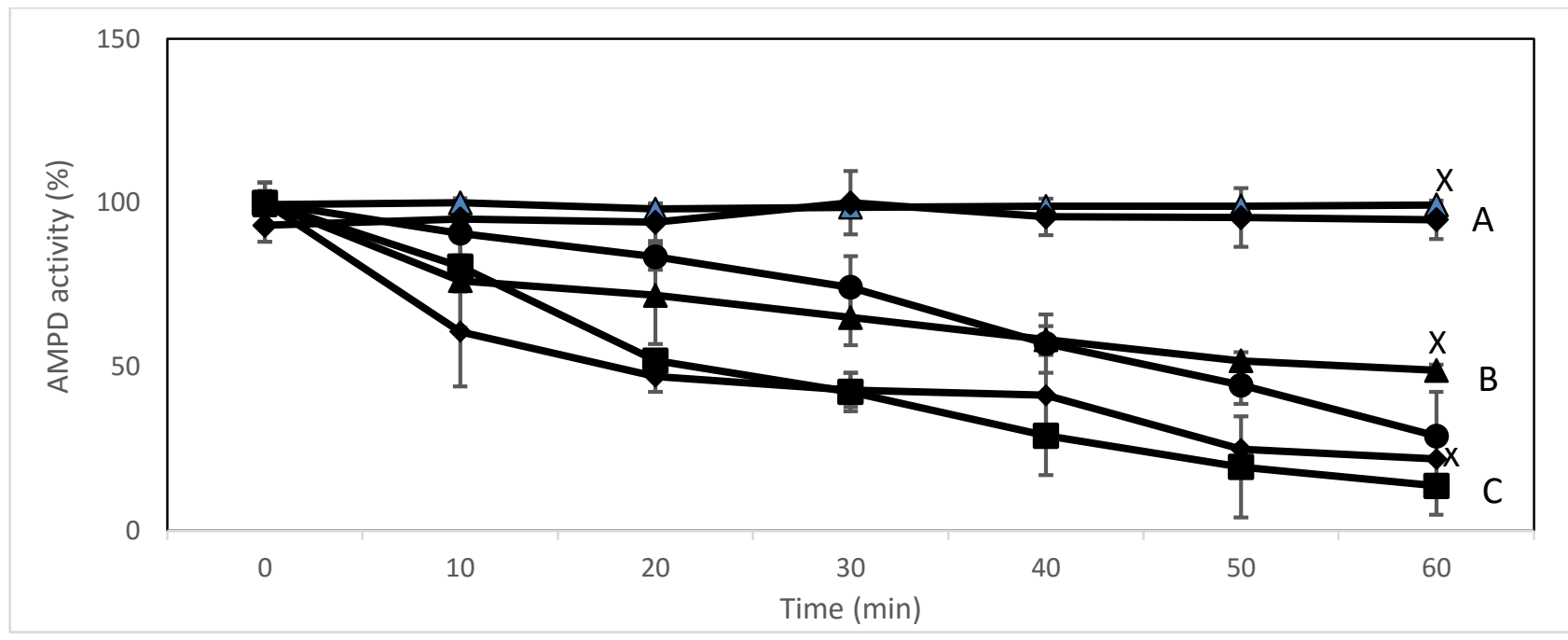

Figure 4. The effects of iron ions, the reagent $\mathrm{FeSO}_{4}$ concentration was $5 \mu \mathrm{M}$, (A). Hydrogen peroxide, $\mathrm{H}_{2} \mathrm{O}_{2}$ concentration was 100 $\mu \mathrm{M}$, (B). And $\mathrm{FeSO}_{4}+\mathrm{H}_{2} \mathrm{O}_{2}$, the reagent concentration was the same as above mentioned(C); On AMPD activity in control $\left({ }^{x}\right)$ and treat $96 \mathrm{~h}$ groups at $25 \circ \mathrm{C}, \mathrm{P}>0.05$ and $\mathrm{n}=3$. 


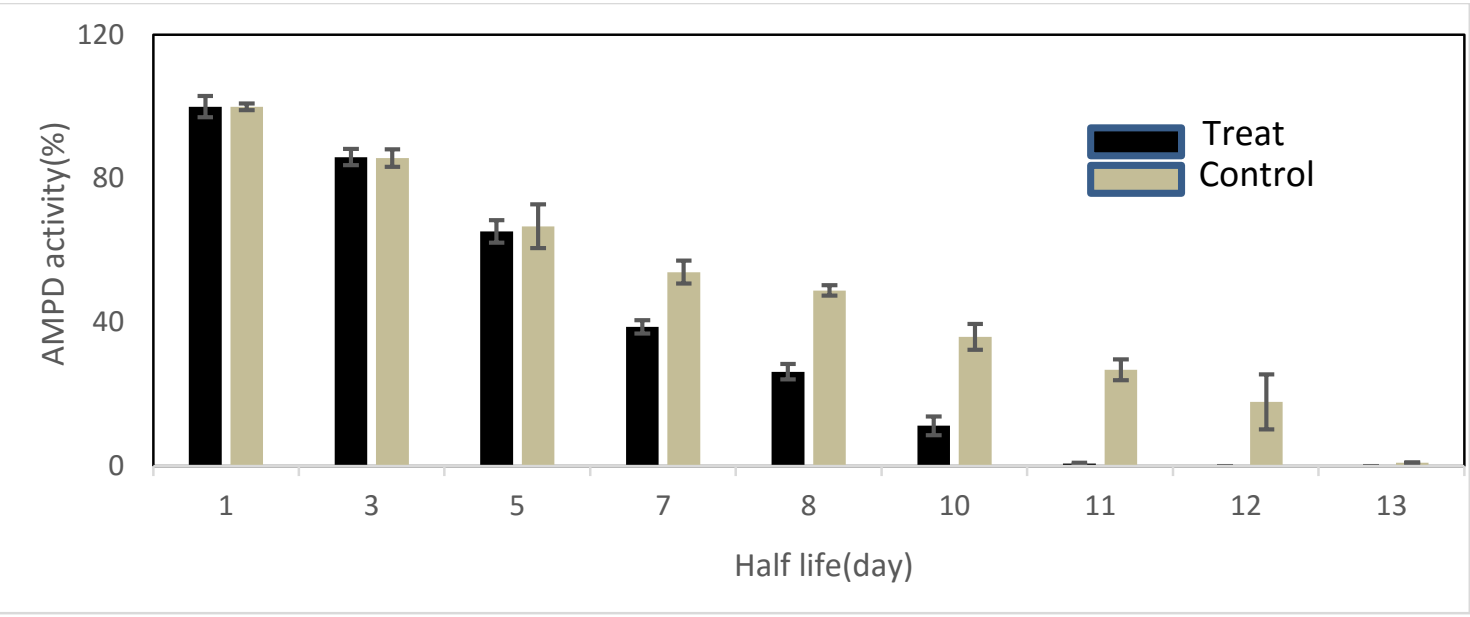

Figure 5. The relationship between the enzyme activity and stability over time in samples exposed to nitrite for $96 \mathrm{~h}$ and the control group, $\mathrm{P}<0.001$ and $\mathrm{n}=3$.

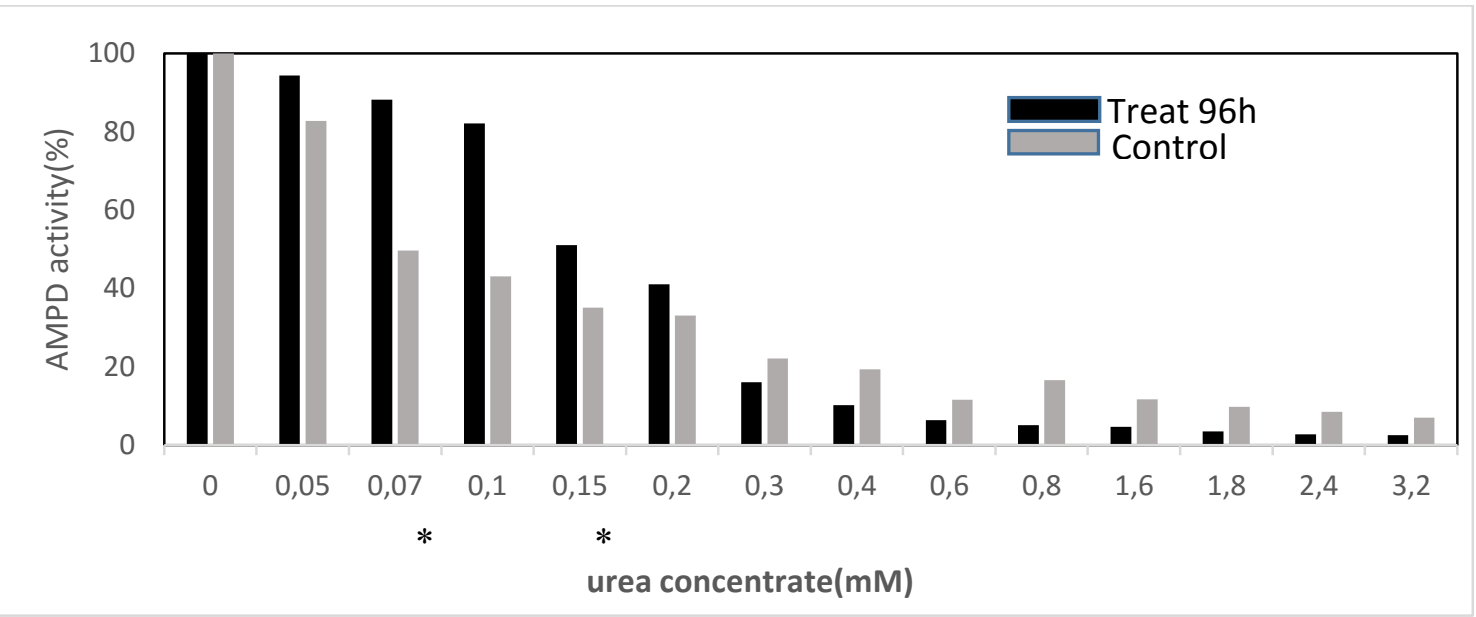

Figure 6. The effects of different concentrations of urea on AMPD activity (\%) after $96 \mathrm{~h}$. The star indicates a significant difference in compare to the control group $(\mathrm{P}<0.001)$.

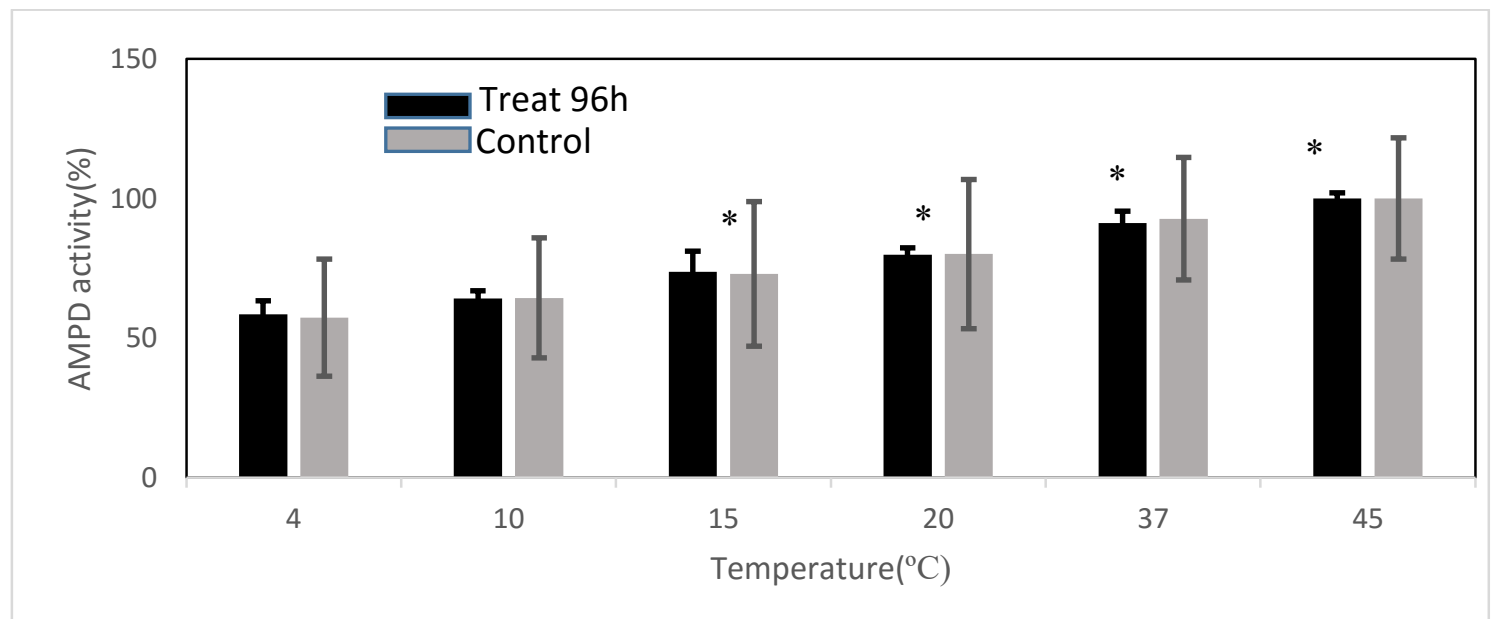

Figure 7. The effect of temperatures $(4,10,15,20,37$, and 45ㅇ) on AMPD activity (\%) in samples exposed to nitrite for $96 \mathrm{~h}$ and the control group, $P>0.05$ and $n=3$. The star indicates a significant difference in compare to the control group. 


\section{Discussion}

Unfortunately, the removal of industrial pollution from water sources seems to be unachievable, so rearing tolerant species in polluted water helps to compensate for this unfavorable situation. Nitrite accumulation results in the oxidation of hemoglobin and disruption of oxygen transmission. Response to hypoxia requires energy that is supplied through two pathways: phosphagens (ATP and phosphocreatine) and glycolysis. ATP utilization results in a drop in the concentrations of phosphagens and an increase in the AMP and ADP levels (Hochachka \& Somero, 1984; Korzeniewski, B, 2005; Nimmo \& Ekblom, 2007; Valberg, S.J, 2008). The present study showed that AMP deaminase activity was strongly affected by $\mathrm{pH}$ (Figure 3 ). In the experimental groups and control, the maximal activity was observed at $\mathrm{pH} 6.5$ and 7 , respectively. At pH 6, the activity of AMPD in the experimental group decreased by 1.2 -fold compared to that of the control group. With the increase in the $\mathrm{pH}$ to 6.5 and 7 in the experimental and control group, the activity of AMPD was recorded to decrease by 2 - and 1.2-fold, respectively; this finding is similar to those of the previous reports (Lushchak et al., 1998, Korzeniewski, B, 2005; Lushchak, 2008). The discrepancy between the maximum activity in various $\mathrm{pH}$ concentrations shows that the adaptation occurred. $\mathrm{PH}$ fell in both toxicity and hypoxia due to the anaerobic glycolysis, so AMPD was activated at lower $\mathrm{pH}$ concentrations. This finding suggests that the active site of the enzyme may contain an ionized group which can easily be protonated and deprotonated under these conditions. Evidence supporting this notion is provided by Lushchak et al. $(2008,1998)$. So.5 for AMP in common carp rose with an increase in the $\mathrm{pH}$ (Lushchak et al., 2008), but an opposite pattern was found in the sea scorpion (Lushchak et al., 1998).

The Hill coefficient was higher than 1 in all groups $(P<0.05)$, showing that the subunits of AMP deaminase were an allosteric enzyme, which cooperated with the substrate in the process of binding. The $V_{\max }$ reduction $(P<0.05)$ in the experimental groups in comparison with that of the control indicated that the enzyme saturated at a lower concentration of the substrate. At acidic $\mathrm{pH}$, the activity of the enzyme increased $(P<0.05)$ by the protonation of the substrate-binding site of AMPdeaminase, which increased the enzyme-substrate affinity and accelerated the reduction of $S_{0.5}(P<0.05)$. The reduction in the S0.5 occurred in groups that had been exposed to nitrite, leading to the activation of AMP deaminase and an increase in the IMP and ammonia.

In the face of stressful conditions, during which the $\mathrm{pH}$ decreases and AMP is accumulated, the body needs energy to preserve the viability of cells. AMPD is a sensor of the energy demands of the cells. AMP deaminase catalyzes the hydrolysis AMP to IMP and $\mathrm{NH}_{3}$ and is a key element in maintaining cellular energy (Sabina \& Holmes, 1990; Lushchak et al., 2008, Hancock, 2006; Kosenko \& Kaminsky, 2010).
Increased enzyme activity induces purine nucleotide cycle activity, which closely parallels the enhancement of oxidative phosphorylation pathway and the increase in the fumarate production (Mommsen \& Hochachka, 1988; Schulte, Moyes, \& Hochachka, 1992; Lushchak \& Storey, 1994a; Lowenstein, 1972; Ohlendieck, 2010), or provides the cells with energy by anaerobic glycolysis by using malate-aspartate shuttle and converting fumarate to malate.

The high nitrite $L C_{50}$ and enzyme half-life suggesting that the common carp have low susceptibility to high concentration of nitrite in water (Figure 5), so it could be concluded that Common carp could overcome the results of increased content of nitrite in water such as hypoxia. Similar to our findings, Lushchak et al. (2005) reported that goldfish, Carassius auratus, could survive in hypoxic and anoxic conditions. Common carp can successfully survive in hypoxic, anoxic, and hyperoxic environments and is highly tolerant of stress caused by free radicals (Storey, 1996; Lushchak \& Bagnyukova, 2006). Nitrite exposure in aquatic ecosystems can induce the formation of ROS and RNS in organisms, which then affects the antioxidant system and other macromolecules (Jensen et al., 2015; Jensen and Hansen, 2011; Sun et al., 2014). In addition, Nitrite exposure oxidizes hemoglobin in hemocytes, increases the amount of methemoglobin, and then causes hypoxia in organisms, which may cause overproduction of ROS (Cheng et al., 2016; Meinelt et al., 2010). As reported in other species, Fenton reaction can be helpful in elucidating adaptation to these environments (Lushchak et al., 1998).

We analyzed the separate effect of any part of the system. $\mathrm{FeSO}_{4}$ did not affect the AMPD activity in either of the groups ( $P>0.05$, Figure $4 A)$. Iron ions present in the assay buffer and muscle extracts had no effect on the AMPD activity. To form the Fenton system to produce Hydroxyl radicals, in addition to iron, hydrogen peroxide is also needed. Since hydrogen peroxide is not present in the environment that was not activated the Fenton system. However, when the AMPD activity was assayed in volume reaction with $\mathrm{H}_{2} \mathrm{O}_{2}$, it reached halfmaximal activity after $~ 50 \mathrm{~min}$ in the control and the treat $96 \mathrm{~h}$. This reduction may be due to the Fenton created by iron ions present in the environment (Figure 4B). While a combination of $\mathrm{FeSO}_{4}$ and $\mathrm{H}_{2} \mathrm{O}_{2}$ was used, the enzyme activity was reduced for $50 \%$ after $20 \mathrm{~min}$ in the control group; almost the same result was observed in the $96 \mathrm{~h}$ group. No significant difference was recorded between the control and experimental groups $30 \mathrm{~min}$ after the start of the reaction ( $P>0.05$, Figure $4 C$ ).

Therefore, our finding shows two aspects compatibility: approximately, no significant differences between control and experimental groups recorded that suggesting enzyme compatibility to free radicals in experimental groups and or free radical with inactivation of AMPD increases its protection effect by increase adenosine production and blood supply to the muscle. 
The $I_{50}$ for AMP was higher in the experimental groups than that of the control group $(P<0.0001)$. This means that the enzyme from the muscle of the fish was inhibited $50 \%$ by more urea value and that is another reason for the high adaptation observed in common carp. The molecular mass of AMPD is different from that of other species, such as human uterine $37 \mathrm{kDa}$ (NagelStarczynowska, Nowak, \& Kaletha, 1991), chick muscle 69 kDa (Sammons \& Chilson, 1978), trout muscle 71.6 kDa (Lushchak \& Storey, 1994b), and equine muscle 76 kDa (Raffin \& Thebault, 1991), and common carp muscle $55 \mathrm{kDa}$ (Lushchak et al., 2008). The variation in the AMPD molecular mass could be due to the limited proteolysis, degradation, interspecies or intertissue specificity, and cross-link during purification.

The calculated activity for the enzyme increased at higher temperatures; this heightened activity actually caused enzyme activation, which is beneficial to enzyme function. The increased enzyme activity could be correlated with 2 potential contribute to binding, hydrogen and hydrophobic binding. At high assay temperatures, it tends to stabilize hydrophobic interactions and activate the enzyme. Also, the activation energy decreased by 1.9-fold in the experimental group, indicating that lower energy is required for reaching the transition state and removing AMP as the energy source.

There are strong evidences that during nitrite intoxication, AMP deaminase activity increase like other enzymes included in energy metabolism such as glycogen phosphorylase and phosphofructokinase (Storey, 1991, Martinez, M.L, 2006). Also hypoxia caused by nitrite intoxication decrease $\mathrm{pH}$ by producing lactate during anaerobic glycolysis (Hochachka \& Somero, 1984; Nimmo \& Ekblom, 2007). The results of our experiment showed that AMP deaminase was activated at lower $\mathrm{pH}$, resistant to radicals caused by the Fenton system and Also urea toxicity increased. All of these changes indicated adaptation to stressful conditions that suggesting when Common carp exposed to nitrite toxicity, this enzyme is responsible for maintaining the energy level It could be concluded that Common carp overcomes situation induced by nitrite intoxication by altering the activity of AMP deaminase.

\section{Acknowledgments}

The authors wish to express their gratitude to the research council of Shahid Chamran University for their financial support.

\section{References}

Bickler, P.E., \& Buck, L.T. (2007). Hypoxia tolerance in reptiles, amphibians, and fishes: life with variable oxygen availability. Annual review of physiology, 69, 145-70. https://doi.org/10.1146/annurev.physiol.69.031905.16 2529. PMID: 17037980

Bradford, M.M. (1976). A rapid and sensitive methode for the quantitiation of microgram qunantities of protein using the principle of protein-dye binding. Analytical Biochemistry, 72(1-2), 248-254.

https://doi.org/10.1016/0003-2697(76)90527-3

Camargo, J.A., \& Alonso, A. (2006). Ecological and toxicological effects of inorganic nitrogenpollution in aquatic ecosystems: a global assessment. Environment International. 32(6), 831-849.

https://doi.org/10.1016/j.envint.2006.05.002. PMID: 16781774

Chaplin, M. (2014). Effect of temperature and pressure. Enzyme Technology

Cheng, A.J., Yamada, T., Rassier, D.E., Andersson, D.C., Westerblad, H., \& Lanner, J.T. (2016). Reactive oxygen/nitrogen species and contractile function in skeletal muscle during fatigue and recovery. The Journal of Physiololgy. 594(18), 5149-5160. https://doi.org/10.1113/JP270650

Eddy, F.B., \& Williams, E.M. (1987). Nitrite and freshwater fish. Journal Chemistry and Ecology, 3(1), 1-38. https://doi.org/10.1080/02757548708070832

Fagernes, C.E., Stensløkken, K., Røhr, Å.K., Berenbrink, M., Ellefsen, S., \& Nilsson, G.E. (2017). Extreme anoxia tolerance in crucian carp and goldfish through neofunctionalization of duplicated genes creating a new ethanol-producing pyruvate decarboxylase pathway. Scientific Reports. 7, 7884.

https://doi.org/10.1038/s41598-017-07385-4.

Fago, A., \& Jensen, F.B. (2015). Hypoxia tolerance, nitric oxide, and nitrite: lessons from extreme animals. Physiology (Bethesda, Md.). 30(2):116-26. https://doi.org/10.1152/physiol.00051.2014.

Gattuso, J.P., Magnan, A.K., Bopp, L., Cheung, W.W.L., Duarte, C.M., Hinkel, J., Mcleod, E., Micheli, F., Oschlies, A., Williamson, P., Billé, R., Chalastani, V.I., Gates, R.D., Irisson, J.O., Middelburg, J.J., Pörtner, H.O., \& Rau, G.H. (2018). Frontiers in Marine Science. Ocean Solutions to Address Climate Change and Its Effects on Marine Ecosystems, 5, 337.

https://doi.org/10.3389/fmars.2018.00337.

Hancock, C.R., Brault, J, J., \& Terjung, R.L. (2006). Protecting the cellular energy state during contractions: role of AMP deaminase. Journal of physiology and pharmacology. 57 (10), 17-29. PMID: 17242488

Hermes-Lima, N., \& Zeneto- Savin, T. (2002). Animal response to drastic changes in oxygen availibility and physiological oxidative stress. Comparative biochemistry and physiology Part C, 133(4), 537-556. https://doi.org/10.1016/s1532-0456(02)00080-7

Hochachka, P.W., \& Somero, G.N. (1984). Biochemical Adaptation. Princenton, USA, Princeton University Press, 560 p.

Jensen, F.B. (2003). Nitrite disrupts multiple physiological functions in aquatic animals. Comparative Biochemistry and Physiology Part A: Molecular \& Integrative Physiology, 135(1), 9-24. https://doi.org/10.1016/S1095-6433(02)00323-9

Jensen, F.B., \& Hansen, M.N. (2011). Differential uptake and metabolism of nitrite in normoxic and hypoxic goldfish. Aquatic Toxicology. 101(2), 318-325. https://doi.org/10.1016/j.aquatox.2010.11.007

Korzeniewskia, B., Nomaa, A., \& Matsuoka, S. (2005). Regulation of oxidative phosphorylation in intact mammalian heart in vivo. Biophysical Chemistry. 116(2), 145- 157. 
https://doi.org/10.1016/j.bpc.2005.04.001 PMID: 15950827

Kosenko, E.A., \& Kaminsky, Yu. G. (2010). Activation of AMP Deaminase and Adenosine Deaminase in the Liver during Ammonia Poisoning and Hepatitis. Bulletin of Experimental Biology and Medicine. 150, 36-38. HTTPS://DOi.ORG/10.1007/s10517-010-1061-6

Kroupova, H. Machova, J. Piackova, V. Flajshans, M. Svobodova, Z., Poleszczuk, G. (2006). Nitrite intoxication of common carp (Cyprinus carpio L.) at different water temperatures. 75(4):561-569. https://doi.org/10.2754/avb200675040561

Kroupova, H.A., Prokes, M., Macova, S., Penaz, M., Barus, V., Novotny, L., \& Machova, J. (2010). Effect of nitrite on early-Life stages of common carp (Cyprinus carpio). First International Workshop on Aquatic Toxicology and Biomonitoring. 29(3), 535-540.

Kroupová, H.K., Valentová, O., Svobodová, Z., Sauer, P., \& Máchová, J. (2016). Toxic effects of nitrite on freshwater organisms: a review. Reviews in Aquaculture. 1-18. https://doi.org/10.1111/raq.12184

Laemmli, U.K. (1970). Cleavage of structural proteins during the assembly of the head of bacteriophage T4. Nature, 227(5259), 680-685. https://doi.org/10.1038/227680a0

Lewis, W.M., \& Morris, D.P. (1986). Toxicity of nitrite to fish: a review. Transactions of the American Fisheries Society, 115(2), 183-195. https://doi.org/10.1577/15488659(1986)115<3C183:TONTF>3E2.0.CO;2

Lowenstein, J.M. (1972). Ammonia production in muscle and tissues the purine nucleotide cycle. Physiological Reviews, 52(2), 382-414. https://doi.org/10.1152/physrev.1972.52.2.382

Lushchak, V.I., Lushchak, L.P., Mota, A.A., \& Hermes-Lima, M. (2001). Oxidative stress and antioxidant defenses in goldfish Carassius auratus and reoxygenation. American Journal of Physiology. Regulatory, integrative and Comparative Physiology, 280, R100-R107. https://doi.org/10.1152/ajpregu.2001.280.1.R100

Lushchak, V.I., \& Bagnyukova, T.V. (2006). Effects of different environmental oxygen levels on free radical processes in fish. Comparative Biochemistry and Physiology. Part B, Biochemistry \& Molecular Biology, 144(3), 283-289. https://doi.org/10.1016/j.cbpb.2006.02.014

Lushchak, V.I., \& Storey, K.B. (1994a). Effect of exercise on the properties of AMP-deaminase from trout white muscle. International Journal of Biochemistry, 26(10-11), 13051312. https://doi.org/10.1016/0020-711X(94)90100-7

Lushchak, V.I., \& Storey, K.B. (1994b). Influence of exercise on the distribution of enzymes in trout white muscle and kinetic properties of AMP-deaminase from free and bound fractions. Fish Physiology and Biochemistry, 13(5), 407-418. https://doi.org/10.1007/BF00003420

Lushchak, V.I., Bagnyukova, T.V., Husak, V.V., Luzhna, L.I., Lushchak, O.V., \& Storey, K.B. (2005). Hyperoxia results in transient oxidative stress and an adaptive response by antioxidant enzymes in goldfish tissues. The International Journal of Biochemistry and cell Biology, 37(8), 1670-168.

https://doi.org/10.1016/j.biocel.2005.02.024

Lushchak, V.I., Husak, V.V., \& Storey, K.B. (2008). Regulation of AMP-deaminase activity from white muscle of common carp Cyprinus carpio. Comparative Biochemistry and Physiology, Part B, 149(2), 362-369.

https://doi.org/10.1016/j.cbpb.2007.10.008

Lushchak, V.I., Smirnova, Y.D., \& Storey, K.B. (1998). AMP- deaminase from sea scorpion white muscle: properties and redistribution under hypoxia. Comparative Biochemistry and Physiology Part B: Biochemistry and Molecular Biology, 119(3), 611-618. https://doi.org/10.1016/S0305-0491(98)00035-2

Mandic, M., \& Regan, M.D. (2018). Can variation among hypoxic environments explain why different fish species use different hypoxic survival strategies? The Journal of experimental biology. https://doi.org/10.1242/jeb.161349. PMID: 30381477

Martinez, C.B., \& Souza, M.M. (2002). Acute effects of nitrite on ion regulation in two neotropical fish species. Comparative biochemistry and physiology. Part A, Molecular \& integrative physiology. 133(1), 151-60. https://doi.org/10.1016/s1095-6433(02)00144-7. PMID: 12160881

Martínez, M.L., Landry, C., Boehm, R., Manning, S., Cheek, A.O., \& Rees, B.B. (2006). Effects of long-term hypoxia on enzymes of carbohydrate metabolism in the Gulf killifish, Fundulus grandis. The journal of experimental biology. 209, 3851-3861. https://doi.org/10.1242/jeb.02437. PMID:16985201

McCue, M.E., Valberg, S.J., Miller, M.B., Wade, C., DiMauro, S., Hasan O Akman, H.O., \& Mickelson, J.R. (2008). Glycogen synthase (GYS1) mutation causes a novel skeletal muscle glycogenosis. 91(5): 458-466. https://doi.org/10.1016/j.ygeno.2008.01.011. PMID: 18358695

Lardon, I., Eyckmans, M., Vu, T.N., Laukens, K., Boeck, G.D., Dommisse, R., et al. (2013a). 1H-NMR study of the metabolome of a moderately hypoxia tolerant fish, the common carp (Cyprinus carpio). Metabolomics. 9, 12161227. https://doi.org/10.1007/s11306-013-0540-y

Mommsen, T.P., \& Hochachka, P.W. (1988). The purine nucleotide cycle as two temporally separated metabolic units: a study on trout muscle. Metabolism Clinical and Experimental, 37(6), 552-556. https://doi.org/10.1016/0026-0495(88)90170-9

Moyson, S; Liew, H.J., Diricx, M., Sinha, A.K., Blust, R., \& Boeck, G.D. (2013). The combined of hypoxia and nutritional status on metabolic and ionoregulatory responses of common carp (Cyprinus carpio). Comparative Biochemistry and Physiology Part A: Molecular \& Integrative Physiolgy. 179, 133-143. https://doi.org/10.1016/j.cbpa.2014.09.017

Nagel-Starczynowska, G., Nowak, G., \& Kaletha, K. (1991). Purification and properties of AMP-deaminase from human uterine smooth muscle. Biochimica et Biophysica Acta, 1073(3), 470-473. https://doi.org/10.1016/03044165(91)90217-5

Nimmo, M.A., \& Ekblom, B. (2007). Fatigue and illness in athletes. Journal of Sports Sciences, 25(S1), S93-S102. https://doi.org/10.1080/02640410701607379

Ohlendieck, K. (2010). Proteomics of skeletal muscle glycolysis. Biochimica et Biophysica Acta. 1804(11), 2089-2101. https://doi.org/10.1016/j.bbapap.2010.08.001 PMID: 20709194

Omlin, T., \& Weber, J.M. (2010). Hypoxia stimulates lactate disposal in rainbow trout. Journal experimental biology. The Journal of Experimental Biology. 213, 3802-3809. https://doi.org/10.1242/jeb.048512. PMID: 21037059

Qin, B., Xu, P., Wu, Q., Luo, L., \& Zhang, Y. (2007). Environmental issues of Lake Taihu, China. Hydrobiologia 581, 3-14. https://doi.org/10.1007

Raffin, J.P., \& Thebault, M.T. (1991). AMP deaminase from 
equine muscle: purification and determination of regulatory properties. The International Journal of Biochemistry, 23(10), 1069-1078.

https://doi.org/10.1016/0020-711x(91)90147-f

Russo, R.C. (1985). Ammonia, nitrate and nitrite. In G.M. Rand, \& S.R. Petrocelli, (Eds), Fundamentals of Aquatic Toxicology (pp. 455-471). Washington DC, USA, Hemishphere Publishing Corporation, 1125 pp.

Sabina, R.L., \& Holmes, E.W. (1990). Myoadenylate deaminase deficiency. In C.R. Scriber, A.L. Beaudet, W.S. Sly, \& D. Valle (Eds.), The Metabolic Basis of Inherited Disease vol. 2 (pp 1769-1780). New York, USA, McGraw-Hill, 4698 pp.

Sammons, D.W., \& Chilson, O.P. (1978). AMP-deaminase: stage-specific isozymes in differentiating chick muscle. Archives of Biochemistry and Biophysics, 191(2), 561570. https://doi.org/10.1016/0003-9861(78)90394-6

Schulte, P.M., Moyes, C.D., \& Hochachka, P.W. (1992). Integrating metabolic pathways in post-exercise recovery of white muscle. The Journal of Experimental Biology, 166, 181-195. PMID: 1602273

Smiley, K.L., Berry, A.J., \& Suelter, C.H. (1967). An improved purification, crystallization, and some properties of rabit muscle 5'-adenilic acid deaminase. The Journal of Biological Chemistry, 242(10), 2502-2506. PMID: 6026241

Storey, K.B. (1991). Metabolic consequences of exercise in organs of rainbow trout. Journal of Experimental Zoology, 260, 157-164. https://doi.org/10.1002/jez.1402600204

Storey, K.B. (1996). Oxidative stress: Animal adaptations in nature. Brazilian Journal of Medical and Biological Research, 29(12), 1715-1733. PMID: 9222437

Sun, Q., Li, L., Huihua, Y., Xiaoting, H., Hui, S., \& Zhaoqi, P. (2014). Influence of the surface hydroxyl groups of MnOx/SBA- 15 on heterogeneous catalytic of oxalic acid. Chemical Engineering Journal, 242, 348-356. https://doi.org/10.1016/j.cej.2013.12.097

Svobodova, Z., Machova, J., Polszczuk, G., Huda, J.,
Hamackova, J., \& Kroupova, H. (2005). Nitrite poisoning of fish in aquaculture facilities with water-recirculating systems; three case studies. Acta Veterinaria Brno, 74, 129-137. https://doi.org/10.2754/avb200574010129

Thomas Meinelt, T., Kroupova, H.K., Stüber, A., \& Rennert, B. (2010). Can dissolved aquatic humic substances reduce the toxicity of ammonia and nitrite in recirculating aquaculture systems? 306(1-4), 378-383. https://doi.org/10.1016/j.aquaculture.2010.06.007

Vornanen, M., Stecyk, J.A.W., \& Nilsson, G.E.b (2009). Chapter 9 The Anoxia-Tolerant Crucian Carp (Carassius Carassius L.). Fish Physiology, 27, 397-441. https://doi.org/10.1016/S1546-5098(08)00009-5

Voslarova, E., Pistekova, V., Svobodova, Z., \& Bedanova, I. (2008). Nitrite toxicity to Danio rerio: effects of subchronic exposure on fish growth. Acta veterinaria Brno, 77, 455-460.

https://doi.org/10.2754/avb200877030455

Wang, Y.S., \& Richards, J. G. (2011). Hypoxia | Anaerobic Metabolism in Fish. Encyclopedia of Fish Physiology. 3, 1757-1763. https://doi.org/10.1016/B978-0-12-3745538.00154-4

Woo, N.Y.S., \& Chiu, S.F. (1997). Metabolic and osmoregulatory responses of the sea bass Lates calcarifer to nitrite exposure. Environmental Toxicology. 12(3), 257-264. https://doi.org/10.1002/(SICI)10982256(1997)12:33.3.CO;2-P

Zhang, H., Choi, H.J., \& Huang, C.P. (2005). Optimization of Fenton process for the treatment of landfill leachate. 125(1-3), 166-74.

https://doi.org/10.1016/j.jhazmat.2005.05.025. PMID: 16011874

Zhang, W., Jiajia, L., Chen, Y., Si, Q., Tian, J., Jiang, Q., \& Yang, J. (2019). Exposure time relevance of response to nitrite exposure: Insight from transcriptional responses of immune and antioxidant defense in the crayfish, Procambarus clarkia. Aquatic Toxicology. https://doi.org/10.1016/j.aquatox.2019.105262 